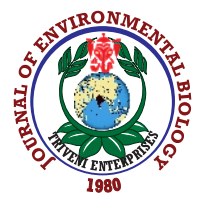

\title{
Effect of FYM and sources of water on growth, yield and soil chemical properties after harvest of wheat (Triticum aestivum $L$ ) in salt affected soils
}

\author{
J.K. Malav*, R.P. Pavaya ${ }^{1}$ and S. Kumar ${ }^{2}$ \\ 'Department of Agricultural Chemistry \& Soil Science, C.P. College of Agriculture, S.D. Agricultural University, Sardarkrushinagar-385 506, India \\ ${ }^{2}$ Agroforestry Research Station, S.D. Agricultural University, Sardarkrushinagar-385 506, India
}

*Corresponding Author Email : jkmalav@sdau.edu.in

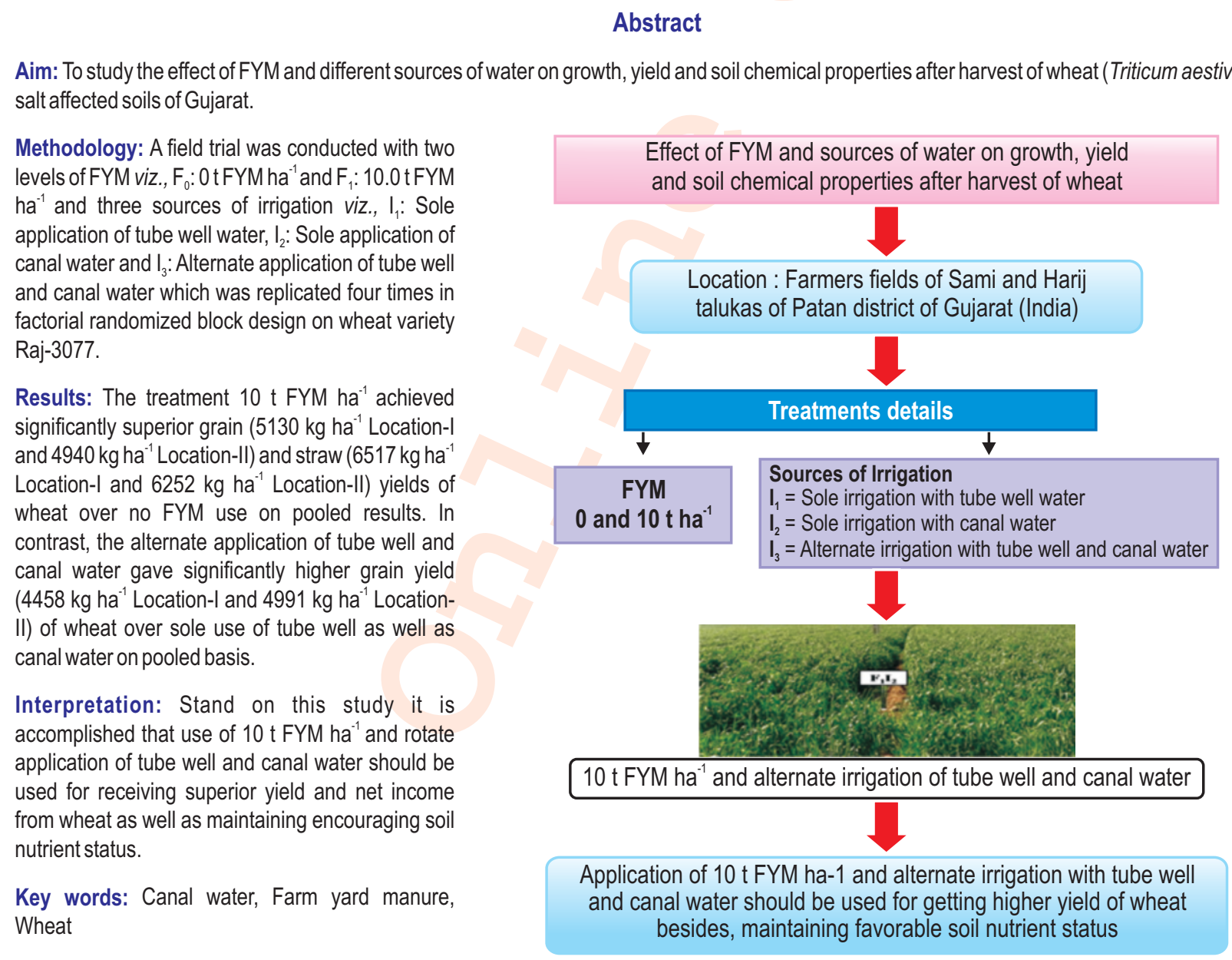

How to cite : Malav, J.K., R.P. Pavaya and S. Kumar: Effect of FYM and sources of water on growth, yield and soil chemical properties after harvest of wheat (Triticum aestivumL) in salt affected soils. J. Environ. Biol., 41, 1696-1702 (2020). 


\section{Introduction}

Wheat is one of the most important staple food and generally cultured chief cereal crop equally in acreage and in production amidst the grain crops of the globe. In excess of one third of the human population is fed by wheat (Sajid et al., 2017). In India, wheat is second crucial clip food crop, rice being the first. Wheat has a relatively high content of niacin and thiamine. Wheat proteins have meticulous significance besides, their consequence in nutrition. In India, the total cultivable area of wheat is $30.63 \mathrm{~m} \mathrm{ha}^{-1}$ with the production of $99.60 \mathrm{mt}$ and average productivity of $3047 \mathrm{~kg} \mathrm{ha}^{-1}$ (Agricultural Statistics at a Glance, 2018). Low production of wheat in Gujarat in contrast to Punjab and Haryana is due to arid and semi-arid climate. Salt affected soils are of broad incidence in such regions of Gujarat. These soils are extremely awkward mostly due to their salt substances and low nutrient status. Gujarat constitutes 1.05 million hectares with a production of 3.13 million tones and efficiency of $2932 \mathrm{~kg}$ ha-1 (Agricultural Statistics at a Glance, 2018). In Gujarat, wheat is being cultured beneath irrigated as well as rain fed situation. Gujarat stands $8^{\text {th }}$ in area, $6^{\text {th }}$ in production and $5^{\text {th }}$ in terms of wheat yield per hectare in India. The majority wheat rising districts of are Banaskantha, Mehsana, Kheda, Ahmedabad, Junagadh, Rajkot, Bhavnagar and Sabarkantha.

In India, totally salt exaggerated area is $6.74 \mathrm{~m}$ ha out of which 3.79 and $2.95 \mathrm{~m}$ ha are of sodic and saline soils, respectively. Salinity is one of the critical abiotic stress factors, which reduces crop production in arid and semi-arid areas, as it contains sufficient salt in the root zone to change the growth of crops. In addition, low precipitation is insufficient for leaching, salt below root zone level (Zhao et al., 2007). Extreme soluble salts in the root zone slow down plant roots from withdrawing water from adjacent soil even though sufficient plant available water is present in soil. In addition to this, soil salinity has the ability to change plant growth through advanced concentrations of toxic ions in the soil (Dikilitas, 2012). Indeed ion toxicities are caused by the accretion of sodium, chloride and boron in the tissue of transpiring leaves to destructive levels.

The underground water quality of North Gujarat Agro climatic Zone -IV (Patan, Banaskantha, Kucchh, Mehsana districts) is poor; more than $50 \%$ samples showed higher salinity as compared to sodicity $\left(\mathrm{C}_{4} \mathrm{~S}_{2}\right.$ class). Using these waters for irrigation may lead to secondary salinization in the soil and ultimately affecting the productivity of soil in this region. The problem of soil salinization can only be solved by leaching off dissolved salts with good quality of irrigation water beyond the root zone, which is quite impossible as there is a limited supply good quality water as well as hardpan in sub-surface region, which restricts deep percolation of water and soluble salts. Hence, poor quality water can be managed by adding of farm yard manure (organic amendments) to the soil and conjunctive use of canal water with tube well water which limits soil salinization.
Considering the above facts, the effect of FYM and sources of water on growth, yield and soil chemical properties after harvest of wheat in salt affected soil was investigated in this study.

\section{Materials and Methods}

A field trial was carried out at Sami and Harij talukas of Patan district, Gujarat during rabi period of 2014-15, 2015-16, 2016-17 and 2017-18. The trial was carried out under the direction of Department of Agricultural Chemistry and Soil Science, C.P. College of Agriculture, S.D. Agricultural University, Sardarkrushinagar, Gujarat (India). The trial was taken with two levels of FYM viz., $F_{0}: 0$ tFYM ha ${ }^{-1}$ and $F_{1}: 10.0$ tFYM ha $^{-1}$ and three sources of irrigation viz., $l_{1}$ : Sole application of tube well water, $I_{2}$ : Sole application of canal water and $I_{3}$ : Alternate application of tube well and canal water which was simulated four times with randomized block design with factorial concept and wheat variety Raj-3077 was sown.

Geographically, Sami and Harij are located at $23.6851^{\circ} \mathrm{N}$ latitude, $71.7786^{\circ} \mathrm{E}$ longitudes at an elevation of $84 \mathrm{~m}$. The climate of Sami-Harij region is semi-arid and sub-tropical with hot summer and cold winter. In this area, normally monsoon commences in the month of June and retreats in September. The majority of the rainfall is conventional on or after south-west monsoon currents. The total rainfall of region was ranged between 552-994 mm. Average minimum and maximum temperature of the year of study was $19.5^{\circ} \mathrm{C}$ and $32.5^{\circ} \mathrm{C}$, respectively. Analytical data pertaining to initial soil fertility status, water quality and nutrient content in FYM are given in Table 1.

The nutrient eminence of soil, representative soil sample (0-15 cm depth) from three spots of every net plot after harvest of wheat crop were composed, composited and air dried. These samples were then grinded with wooden mortar and pestle and passed through $2.0 \mathrm{~mm}$ sieve and were investigated for $\mathrm{EC}, \mathrm{pH}$, organic carbon (\%), available $\mathrm{P}_{2} \mathrm{O}_{5}$ and $\mathrm{K}_{2} \mathrm{O}$ status in soil as per standard method. The soil of the trial field was loamy sand in texture, alkaline in nature and soluble salt content under limit. It was low in organic carbon, medium in available $\mathrm{P}_{2} \mathrm{O}_{5}$ and medium to high in available $\mathrm{K}_{2} \mathrm{O}$ status. The yield attributes and yield parameters viz., seed yield, straw yield, no. of effective tillers/plant, plant height $(\mathrm{cm})$, length of spike $(\mathrm{cm})$ and no. of seed/spike recorded from net plot and changed on hectare basis. All the data for different parameters were statistically analyzed using Fishers' analysis of variance (ANOVA) method and the treatments were compared at $5 \%$ level of significance.

\section{Results and Discussion}

The perusal of data given in Table 2 and 3 revealed that application that application of FYM had a significant effect on grain and straw yield, no. of tillers, length of spike, number of seeds/spike and protein content of wheat during all the individual 
Table 1 : Analytical data of initial soil fertility, water quality and nutrient content in FYM

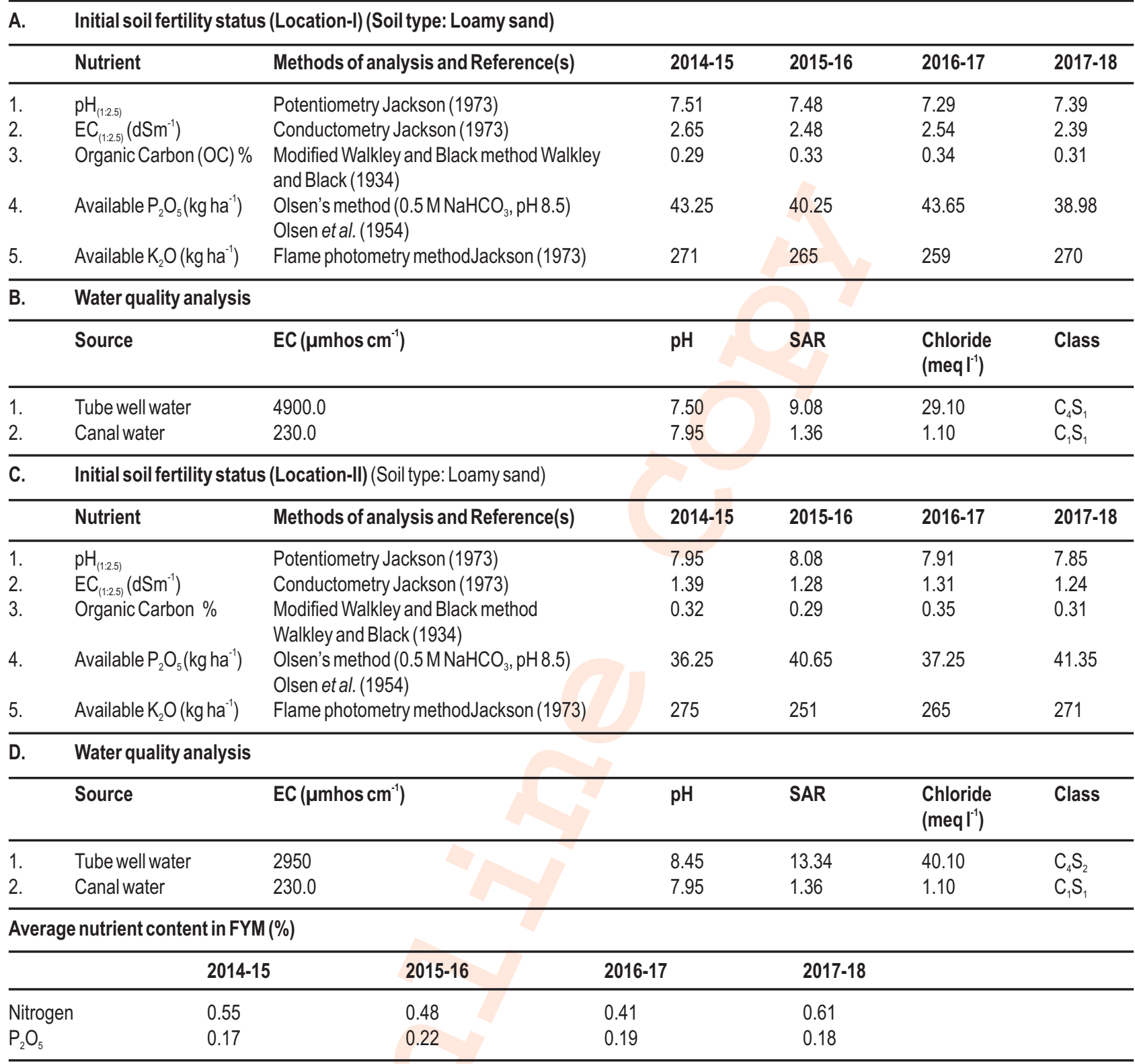

years as well as on pooled basis at both the locations. Application of $10 \mathrm{t} \mathrm{FYM} \mathrm{ha}{ }^{-1}$ gave significantly higher yield of grain (5130 and $4940 \mathrm{~kg} \mathrm{ha}^{-1}$ ) and straw (6517 and $\left.6252 \mathrm{~kg} \mathrm{ha}^{-1}\right)$, no. of tillers (6.56 and 6.45$)$, length of spike (7.51 and $7.83 \mathrm{~cm})$, no. of seeds/spike (33.69 and 33.78) and protein content (13.24 and 13.02\%) in wheat on pooled basis at both the locations. It is fairly apparent that the maximum grain and straw yield was recorded under at 10 t FYM ha ${ }^{-1}$. Starting these results it may be subjective that the expensive effect of FYM is due to its association in supplying additional plant nutrients, enhancement of soil physical, chemical and biological progression in soil. Enhancement in the soil structure due to FYM application leads to enhanced environment for root development. Farm yard manure also advances soil water holding ability. The fact that the use of organic fertilizers to get better soil structure, nutrient exchange and to maintain soil health has elevated advantage of organic farming. The use of FYM alone as an alternate for inorganic fertilizer is not sufficient to maintain the present levels of crop effectiveness of high yielding varieties. In common, the use of natural amendments such as crop residues and/or FYM significantly augments soil organic carbon (Yadav et al., 2000). In diminutive, improved nutrient composition of wheat on applying FYM may be due to enhanced availability of nutrients under sufficient provider of available nutrients.

The statistics obtainable in Table 2 and Table 3 specify that different sources of irrigation had a significant effect on grain 
Table 2 : Effect of different levels of FYM and sources of irrigation on yield and yield attributes of wheat (Pooled data of 4 years)

\begin{tabular}{|c|c|c|c|c|c|c|c|}
\hline \multirow[t]{2}{*}{ Treatments } & \multicolumn{7}{|c|}{ Location-I } \\
\hline & $\begin{array}{l}\text { Grain yield } \\
\left(\mathrm{kg} \mathrm{ha}^{-1}\right)\end{array}$ & $\begin{array}{l}\text { Straw yield } \\
\left(\mathrm{kg} \mathrm{ha}^{-1}\right)\end{array}$ & $\begin{array}{l}\text { No. of effective } \\
\text { tillers/plant }\end{array}$ & $\begin{array}{l}\text { Plant height } \\
\text { (cm) }\end{array}$ & $\begin{array}{l}\text { Length of } \\
\text { spike }(\mathrm{cm})\end{array}$ & $\begin{array}{l}\text { No. of seed/ } \\
\text { spike }\end{array}$ & $\begin{array}{l}\text { Protein } \\
\text { content (\%) }\end{array}$ \\
\hline \multicolumn{8}{|l|}{ Levels of FYM (tha' $\left.{ }^{-1}\right)$} \\
\hline $\mathrm{F}_{0}: 0$ & 4481 & 5723 & 6.13 & 69.75 & 7.13 & 31.31 & 12.58 \\
\hline$F_{1}: 10$ & 5130 & 6517 & 6.56 & 71.84 & 7.51 & 33.69 & 13.24 \\
\hline S.Em+ & 54 & 62 & 0.10 & 1.08 & 0.11 & 0.57 & 0.20 \\
\hline $\mathrm{CD}(0.05)$ & 151 & 176 & 0.28 & NS & 0.32 & 1.61 & 0.56 \\
\hline \multicolumn{8}{|l|}{ Sources of irrigation } \\
\hline $\mathrm{I}_{1}$ & 4015 & 5879 & 5.99 & 69.39 & 7.00 & 31.15 & 12.63 \\
\hline $\mathrm{I}_{2}$ & 4336 & 6169 & 6.42 & 71.01 & 7.37 & 32.88 & 12.96 \\
\hline $\mathrm{I}_{3}$ & 4458 & 6313 & 6.63 & 71.99 & 7.59 & 33.46 & 13.13 \\
\hline S. Em + & 114 & 76 & 0.12 & 1.33 & 0.14 & 0.70 & 0.24 \\
\hline $\operatorname{CD}(0.05)$ & 343 & 216 & 0.34 & NS & 0.39 & NS & NS \\
\hline CV \% & 7.53 & 7.06 & 10.65 & 10.60 & 10.58 & 12.17 & 10.58 \\
\hline \multicolumn{8}{|l|}{ Interactions } \\
\hline FYM x Irrigation & NS & NS & NS & NS & NS & NS & NS \\
\hline FYMxYear & NS & NS & NS & NS & NS & NS & NS \\
\hline Irrigation x Year & NS & NS & NS & NS & NS & NS & NS \\
\hline FYM x Irrigation $x$ Year & NS & NS & NS & NS & NS & NS & NS \\
\hline
\end{tabular}

and straw yield, no. of effective tillers, no. of seeds/spike and length of spike of wheat on pooled basis at both sites. The rotate application of tube well and canal water gave significantly higher grain (4458 and $4991 \mathrm{~kg} \mathrm{ha}^{-1}$ ) and straw (6313 and $\left.6254 \mathrm{~kg} \mathrm{ha}^{-1}\right)$ yield, no. of effective tillers (6.63 and 6.35), length of spike (7.59 and $7.83 \mathrm{~cm}$ ) and no. of seeds/spike (34.06 Location-II) of wheat over sole application of tube well water on pooled basis at both sites, but it was at par with the sole application of canal water in case of grain yield ( $\left.4336 \mathrm{~kg} \mathrm{ha}^{-1}\right)$ of wheat at Location-I. From the data presented in Table 2 and Table 3, it could be inferred that sources of irrigation did not show any significant change in plant height and total number of seeds per spike on pooled basis at both the locations. Yield components and grain yield were reduced significantly with the sole application of tube well water. Sole application of canal water did not show any significant effect of on growth as well as yield and yield attributes except grain yield of wheat at location-I. The results illustrate that use of alternate irrigation of tube well and canal water, the tube well water hold high quantity of mineral elements and unlike kind of salts and the supply of next irrigation through canal water dissolves all mineral and salts present in the soil. Therefore crop utilized all the essential elements mineral and salts, while other perilous salts were leached downward beneath the root zone. Extra salts are impulsive when less irrigation water was applied, particularly if accompanied by lack of rain.

Reduction in grain yield and yield components owed to salinity has also been pragmatic by Saqib et al. (2004) and Ghogdi et al. (2012). Amongst the morphological attributes, utmost reduction was pragmatic in number of tillers per plant which may be due to incorporation of tremendous salts by the plants, which ultimately pretentious the plant growth expansively by declining the quantity of photosynthetic, water or supplementary growth factors (Khathar and Kuhad, 1999). Owing to higher concentrations of salts in the leaves, metabolic processes like photosynthesis and protein synthesis are unconstructively affected leading to condensed grain weight. A positive correlation exists between $\mathrm{Na}+$ keeping out and salt accumulation in lots of crops together with wheat (Shafi et al., 2010; Ghogdi et al., 2012). Under saline conditions, there is unreceptive diffusion of $\mathrm{Na}^{+}$ions during injured membranes and decreased effectiveness of prohibiting mechanism which results in elevated concentration of sodium in leaf sap (Leidi and Saiz, 1997). Potassium influx transporters arbitrate sodium influx into root cells (Rabhi et al., 2007) under saline condition. There was encouraging association of grain yield and quality with the alternating application of canal water and tube well water in this study which shows that dissolved soluble salts and supply of plant nutrients to plant sustain constructive ionic composition helps to tolerate saline conditions.

The data presented in Table 4 and Table 5 reveal that individual effect of FYM and sources of irrigation was found to be non-significant in case of soil $\mathrm{pH}$ and available $\mathrm{K}_{2} \mathrm{O}$ content in soil after harvest of wheat on pooled basis at both the locations, except available $\mathrm{K}_{2} \mathrm{O}$ content at location II. The statistics (Table 4 and Table 5) illustrate that the application of $10 \mathrm{t} \mathrm{FYM} \mathrm{ha}^{-1}$ was found to be significant on electrical conductivity of soil after 
Table 3 : Effect of different levels of FYM and sources of irrigation on yield and yield attributes of wheat (Pooled data of 4 years)

\begin{tabular}{|c|c|c|c|c|c|c|c|}
\hline \multirow[t]{2}{*}{ Treatments } & \multicolumn{7}{|c|}{ Location-II } \\
\hline & $\begin{array}{l}\text { Grain yield } \\
\left(\mathrm{kg} \mathrm{ha}^{-1}\right)\end{array}$ & $\begin{array}{l}\text { Straw yield } \\
\left(\mathrm{kg} \mathrm{ha}^{-1}\right)\end{array}$ & $\begin{array}{l}\text { No. of effective } \\
\text { tillers/plant }\end{array}$ & $\begin{array}{l}\text { Plant height } \\
\text { (cm) }\end{array}$ & $\begin{array}{l}\text { Length of } \\
\text { spike }(\mathrm{cm})\end{array}$ & $\begin{array}{l}\text { No. of seed/ } \\
\text { spike }\end{array}$ & $\begin{array}{l}\text { Protein } \\
\text { content (\%) }\end{array}$ \\
\hline \multicolumn{8}{|l|}{ Levels of FYM (tha' $\left.{ }^{-1}\right)$} \\
\hline $\mathrm{F}_{0}: 0$ & 4310 & 5422 & 5.84 & 67.79 & 7.19 & 31.49 & 12.28 \\
\hline $\mathrm{F}_{1}: 10$ & 4940 & 6252 & 6.45 & 70.70 & 7.83 & 33.78 & 13.02 \\
\hline S. Em + & 66 & 106 & 0.09 & 1.09 & 0.13 & 0.57 & 0.20 \\
\hline $\mathrm{CD}(0.05)$ & 188 & 299 & 0.25 & NS & 0.37 & 1.62 & 0.58 \\
\hline \multicolumn{8}{|l|}{ Sources of irrigation } \\
\hline $\mathrm{I}_{1}$ & 4231 & 5430 & 5.94 & 68.09 & 7.22 & 31.72 & 12.47 \\
\hline $\mathrm{I}_{2}$ & 4653 & 5827 & 6.15 & 69.37 & 7.48 & 32.12 & 12.62 \\
\hline $\mathrm{I}_{3}$ & 4991 & 6254 & 6.35 & 70.29 & 7.83 & 34.06 & 12.85 \\
\hline S. Em+ & 81 & 129 & 0.11 & 1.34 & 0.16 & 0.70 & 0.25 \\
\hline $\operatorname{CD}(0.05)$ & 230 & 366 & 0.30 & NS & 0.45 & 1.98 & NS \\
\hline CV \% & 9.96 & 12.54 & 9.84 & 10.95 & 11.98 & 12.13 & 11.23 \\
\hline \multicolumn{8}{|l|}{ Interactions } \\
\hline FYM x Irrigation & NS & NS & NS & NS & NS & NS & NS \\
\hline FYMxYear & NS & NS & NS & NS & NS & NS & NS \\
\hline Irrigation x Year & NS & NS & NS & NS & NS & NS & NS \\
\hline FYM $x$ Irrigation $x$ Year & NS & NS & NS & NS & NS & NS & NS \\
\hline
\end{tabular}

Table 4: Effect of different levels of FYM and sources of irrigation on the nutrient status after harvest of crop (Pooled data of 4 years)

\begin{tabular}{|c|c|c|c|c|c|}
\hline \multirow[t]{2}{*}{ Treatments } & \multicolumn{5}{|c|}{ Location-I } \\
\hline & $\mathrm{pH}$ & $E C\left(d_{S m}^{-1}\right)$ & $\mathrm{OC}(\%)$ & $\begin{array}{l}\text { Available } \mathrm{P}_{2} \mathrm{O}_{5} \\
\left(\mathrm{~kg} \mathrm{ha}^{-1}\right)\end{array}$ & $\begin{array}{l}\text { Available } \mathrm{K}_{2} \mathrm{O} \\
\left(\mathrm{kg} \mathrm{ha}^{-1}\right)\end{array}$ \\
\hline \multicolumn{6}{|l|}{ Levels of FYM (tha $\left.{ }^{-1}\right)$} \\
\hline $\mathrm{F}_{0}: 0$ & 7.44 & 1.61 & 0.32 & 38.92 & 261 \\
\hline $\mathrm{F}_{1}: 10$ & 7.26 & 1.46 & 0.37 & 44.72 & 273 \\
\hline S.Em+ & 0.08 & 0.02 & 0.01 & 0.79 & 4 \\
\hline $\mathrm{CD}(0.05)$ & NS & 0.06 & 0.02 & 2.25 & NS \\
\hline \multicolumn{6}{|l|}{ Sources of irrigation } \\
\hline $\mathrm{I}_{1}$ : Sole irrigation with tube well water & 7.51 & 2.60 & 0.32 & 39.86 & 263 \\
\hline $\mathrm{I}_{2}:$ Sole irrigation with canal water & 7.26 & 0.67 & 0.35 & 42.43 & 268 \\
\hline 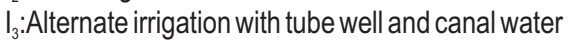 & 7.29 & 1.34 & 0.36 & 43.18 & 270 \\
\hline S.Em+ & 0.10 & 0.02 & 0.01 & 0.97 & 5 \\
\hline $\mathrm{CD}(0.05)$ & NS & 0.07 & 0.02 & 2.75 & NS \\
\hline CV\% & 7.50 & 9.06 & 12.87 & 13.17 & 11.34 \\
\hline $\mathrm{CD}(\mathrm{Y} \times \mathrm{T})$ & NS & NS & NS & NS & NS \\
\hline
\end{tabular}

harvest of wheat on pooled basis at both the locations. Significantly lowest electrical conductivity $\left(1.46 \mathrm{dSm}^{-1}\right.$ and 0.75 $\mathrm{dSm}^{-1}$ ) was observed with the application of $10 \mathrm{t} \mathrm{FYM} \mathrm{ha}^{-1}$ in soil after harvest of wheat on pooled basis at both the locations. The data presented in Table 4 and Table 5 reveal that application of FYM either alone or in combination with NPK resulted in considerable changes of soil organic carbon content in the surface soil layer $(0-15 \mathrm{~cm})$ than that of unfertilized control as well as NPK treated plots. The plots that received $10 \mathrm{t} \mathrm{FYM} \mathrm{ha}^{-1}$ registered significantly higher $(0.34 \%$ to $0.37 \%)$ build-up in soil organic carbon over unfertilized control plots in the surface soil on pooled basis at both sites. The data presented in Table 4 and Table 5 reveal that the application of $10 \mathrm{t} \mathrm{FYM} \mathrm{ha}^{-1}$ gave significantly higher available $\mathrm{P}_{2} \mathrm{O}_{5}$ content $\left(44.72 \mathrm{~kg} \mathrm{ha}^{-1}\right.$ and $40.84 \mathrm{~kg} \mathrm{ha}^{-1}$ ) in soil after harvest of crop over control on pooled basis at both the locations. The data obtainable in Table 5 revealed that the application of $10 \mathrm{t} \mathrm{FYM} \mathrm{ha}^{-1}$ gave significantly higher available $\mathrm{K}_{2} \mathrm{O}$ content $\left(273 \mathrm{~kg} \mathrm{ha}^{-1}\right)$ in soil after harvest of crop over control on pooled basis at site II. The reduction in soil $\mathrm{pH}$ in the FYM applied soil might have resulted due to liberated organic acids and carbon dioxide (CO2) into the soil through the decay of the manure. Invention of aliphatic and aromatic hydroxyl 
Table 5 : Effect of different levels of FYM and sources of irrigation on the nutrient status after harvest of crop (Pooled data of 4 years)

\begin{tabular}{|c|c|c|c|c|c|}
\hline \multirow[t]{2}{*}{ Treatments } & \multicolumn{5}{|c|}{ Location-II } \\
\hline & $\mathrm{pH}$ & $E C\left(d_{S m}^{-1}\right)$ & $\mathrm{OC}(\%)$ & $\begin{array}{l}\text { AvailableP } \mathrm{O}_{5} \\
\left(\mathrm{~kg} \mathrm{ha}^{-1}\right)\end{array}$ & $\begin{array}{l}\text { AvailableK }{ }_{2} \mathrm{O} \\
\left(\mathrm{kg} \mathrm{ha}^{-1}\right)\end{array}$ \\
\hline \multicolumn{6}{|l|}{ Levels of FYM (t/ha) } \\
\hline $\mathrm{F}_{0}: 0$ & 7.81 & 0.88 & 0.31 & 35.44 & 257 \\
\hline$F_{1}: 10$ & 7.66 & 0.75 & 0.34 & 40.84 & 273 \\
\hline S. Em+ & 0.13 & 0.01 & 0.01 & 0.63 & 4 \\
\hline $\mathrm{CD}(0.05)$ & NS & 0.03 & 0.02 & 1.79 & 12.18 \\
\hline \multicolumn{6}{|l|}{ Sources of irrigation } \\
\hline $\mathrm{I}_{1}$ : Sole irrigation with tube well water & 8.03 & 1.21 & 0.31 & 36.87 & 260 \\
\hline $\mathrm{I}_{2}:$ Sole irrigation with canal water & 7.47 & 0.51 & 0.33 & 38.04 & 264 \\
\hline$I_{3}:$ Alternate irrigation with tube well and canal water & 7.70 & 0.72 & 0.35 & 39.49 & 271 \\
\hline S. Em+ & 0.15 & 0.01 & 0.01 & 0.77 & 5 \\
\hline $\operatorname{CD}(0.05)$ & NS & 0.04 & 0.02 & NS & NS \\
\hline CV \% & 11.33 & 8.97 & 12.1 & 11.48 & 11.26 \\
\hline $\mathrm{CD}(\mathrm{Y} \times \mathrm{T})$ & NS & NS & NS & NS & NS \\
\hline
\end{tabular}

acids as a consequence of putrefaction of FYM can also result in complexing of free and exchangeable aluminum ions, thus decreasing the $\mathrm{pH}$ (Grewal et al., 1981). Results of 25 years of nonstop cropping in long term fertilizer trial also revealed that integrated use of NPK and FYM in soybean-wheat system, significantly improved soil organic carbon content in a Haplustalf and Chromustert. Likewise Aoyama et al. (1999b) accounted that after 18 years; manure enlarged the organic matter of whole soil and privileged structure of slaking-resistant macro-aggregates (250-1000 mm). Aoyama et al. (1999b) observed that organic carbon addition through manure led to higher absorption of total carbon in dry sieved macro-aggregates than in micro aggregates.

Continuous application of FYM also condenses the movement of polyvalent cations such as $\mathrm{Ca}, \mathrm{Fe}$ and $\mathrm{Al}$ due to chelation which, in turn, is considered accountable for decrease in P-fixation (Gupta et al., 1988). Application of FYM augmented Olsen- $P$ since of its $P$ content and perhaps by increasing maintenance of $P$ in soil. An optimistic result of FYM on $P$ accessibility was also pragmatic by Roy et al. (2001). Improved soil physical environment attached with competence of water and nutrients helped in superior uptake of water and nutrients resulting in higher yield of wheat in FYM treated plots as compared to that in control plots.

The data presented in Table 4 and Table 5 indicates that the effect of sources of irrigation on electrical conductivity was found significant on pooled basis at both the locations. The results reveal that significantly lowest electrical conductivity $(0.67$ and $0.51 \mathrm{dSm}^{-1}$ ) was observed with the sole application of canal water on pooled basis at both the locations. The data presented in Table 4 and Table 5 reveal that application of alternate irrigation with canal and tube well water significantly increased the organic carbon content $(0.36 \%$ and $0.35 \%)$ in soil after harvest of wheat on pooled basis at both the locations; but it was at par with the sole application of canal water at both the locations on pooled basis. The results showed that use of alternate irrigation of tube well and canal water, the tube well water contains high amount of mineral elements and different types of salts and the supply of next irrigation through canal water dissolved all the mineral and salts in the soil hence, crop utilized all the essential elements mineral and salts while, other hazardous salts are leached down below the root zone. More salts are precipitated when less irrigation water was applied, especially if accompanied by a lack of rain conditions. The data obtainable in Table 4 and Table 5, disclose that different sources of irrigation water did not show any significant change in case of soil $\mathrm{pH}$ and available $\mathrm{K}_{2} \mathrm{O}$ content in soil after harvest of wheat crop on pooled basis at both sites. The application of alternate irrigation with tube well and canal water significantly increased the available $\mathrm{P}_{2} \mathrm{O}_{5}$ content in soil after harvest of wheat at location-I on pooled basis; but it was statistically at par with the sole irrigation with canal water. The interaction effect between different levels of FYM and sources of irrigation on grain and straw yield, total numbers of effective tillers, length of spike and total number of seeds per spike and physicochemical properties of soil were found non-significant on pooled basis at both the locations.

Based on this investigation, it is concluded that application of $10 \mathrm{t} \mathrm{FYM} \mathrm{ha}^{-1}$ and alternate application of tube well and canal water should be used for higher yield of wheat besides, maintaining favorable soil nutrients status.

\section{Acknowledgment}

The authors are grateful to the Department of Agriculture Chemistry and Soil Science, C.P. College, S.D. Agricultural University, Sardarkrushinagar for providing necessary facilities for research work. 


\section{References}

Acharya, C.L., S.K. Bisnoi and H.S. Yaduvanshi: Effect of long-term application of fertilizers and organic and inorganic amendments under continuous cropping on soil physical and chemical properties in an Alfisol. Indian J. Agric. Sci., 509-516(1988).

Agricultural Statistics at a Glance: Government of India Ministry of Agriculture and Farmers Welfare Department of Agriculture, Cooperation and Farmers Welfare Directorate of Economics and Statistics. Visit us at: www.agricoop.nic.in and http:// eands.dacnet.nic.in (2018)

Anonymous: Agricultural Vital Statistics, Ministry of Agriculture, New Delhi, (2010).

Aoyama, M., D.A. Angers, A. N. Dayegamiye and N. Bissonnette: Protected organic matter in water-stable aggregates as affected by mineral fertilizer and manure applications. Can. J Soil Sci., 79, 419-425 (1999b).

Dikilitas, M. and S. Karakas: Behavior of plant pathogens for crops under stress during the determination of physiological, biochemical and molecular approaches for salt stress tolerance. In: Crop Production for Agricultural Improvement, Heidelberg, Germany, Springer, New York, pp. 417-441 (2012).

Ghogdi, E.A., A.I. Darbandi and A. Borzouei: Effects of salinity on some physiological traits in wheat (Triticum aestivum L.) cultivars. Ind. J. Sci. Technol., 5, 1906-1916 (2012).

Grewal, J.S., R.C. Sharma and K.C. Sud: Effect of continuous application of $\mathrm{PK}$ fertilizers and $\mathrm{FYM}$ on potato yield and some soil properties. J. Indian Soc. Soil Sci., 29, 129-131 (1981).

Gupta, A.P., R.S. Antil and R.P. Narwal: Effect of farmyard manure on organic carbon, available N, and P content of soil during different periods of wheat growth. J Indian Soc. Soil Sci., 262, 269-273 (1988).

Jackson, M.L.: Soil Chemical Analysis: Prentice Hall of India Pvt. Ltd., New Delhi (1973).

Khatkar, D. and M.S. Kuhad: Short-term salinity induced changes in two wheat cultivars at different growth stages. Biologia Plantarum, 43, 629-632 (1999).
Kumar, P., A. Singh and A.K. Singh: Effect of bio-fertilizers, farmyard manure and nitrogen levels on growth yield and uptake of nutrients in wheat. Ann. Plant Soil Res., 12, 92-94 (2010).

Leidi, E.O. and J.F. Saiz: Salinity tolerance related to $\mathrm{Na}^{+}$accumulation in upland cotton seedlings. Plant Soil, 190, 67-75 (1997).

Olsen, S.R. and F.S. Watanabe: Test of ascorbic acid method for determining phosphorus in plant and $\mathrm{NaHCO}_{3}$ extract. Soil Sci. American Proc., 29, 677-678 (1954).

Rabhi, M., C. Hafsi, A. Lakhdar, S. Hajji, Z. Barhoumi, M.H. Hamrouni, C. Abdelly and A. Smaoui: Evaluation of the capacity of three halophytes to desalinize their rhizosphere as grown on saline soils under non leaching conditions. Afr. J. Ecol., 47, 463-468 (2007).

Roy, S.K., R.C. Sharma and S.P. Trehan: Integrated nutrient management by using farmyard manure and fertilizers in potato sunflower-paddy rice rotation in the Punjab. J. Agric. Sci., 137, 271-278 (2001).

Sajid, I., U. Saif, M.A. Muhammad, A. Nawab, A. Bilal and A. Sgad: Impact of various levels of phosphorus on wheat. Int. J. Environ. Sci., Nat. Res., 6, MS.ID.555696 (2017).

Saqib, M., J. Akhtar and R.H. Qureshi: Pot study on wheat growth in saline and waterlogged compacted soil on grain yield and yield components. Soil Till. Res., 77, 169-177 (2004).

Shafi, M., J. Bakht, M.J. Khan, M.A. Khan and S. Anwar: Effect of salinity on yield and ion accumulation of wheat genotypes. Pak. J. Bot., 42, 4113-4121 (2010).

Sisodia, R.S., M. Pandey and A. Pal: Response of oat to FYM under sodic water irrigation. Ann. Pl. Soil Res., 12, 86-88 (2010).

Walkley, A. and I.A. Black: An examination of Digestion method for determining soil organic matter and a proposed modification of chromic acid titration method. Soil Sci., 34, 29-38 (1935).

Yadav, R.L., B.S. Dwivedi, K. Prasad, O.K. Tomar, N.J. Shurpali and P.S. Pandey: Yield trends and changes in soil organic $C$ and available NPK in a long-term rice-wheat system under integrated use of manures and fertilizers. Field Crops Res., 68, 219-246 (2000).

Zhao, J., W. Ren, D. Zhi, L. Wang and G. Xia: Arabidopsis DREB1A/CBF3 bestowed transgenic tall rescue increased tolerance to drought stress. Plant Cell Rep., 26, 1521-1528 (2007). 